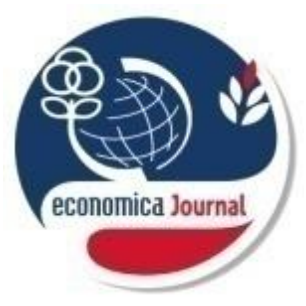

ISSN : $2302-1590$

E-ISSN: $2460-190 X$

ECONOMICA

Jurnal Program Studi Pendidikan Ekonomi

STKIP PGRI Sumatera Barat Vol.8 No.1 (1-11)

\title{
THE IMPACT OF TRANSFORMATIONAL LEADERSHIP AND JOB SATISFACTION ON READINESS TO CHANGE
}

\author{
By \\ Ramdani Bayu Putra ${ }^{1)}$ Hasmaynelis Fitri ${ }^{2)}$ \\ ${ }^{1)}$ Fakultas Ekonomi dan Bisnis, Universitas Putra Indonesia YPTK Padang \\ Email: ramdhani_bayu@upiyptk.ac.id \\ 2) Fakultas Ekonomi dan Bisnis, Universitas Putra Indonesia YPTK Padang \\ Email: hasmaynelisfitri@upiyptk.ac.id \\ Submited: 2019.09.14 Reviewed: 2019.10.18 Accepted:2019.10.24 \\ https://doi.org/10.22202/economica.2019.v8.i1.3587
}

\begin{abstract}
Readiness to change is an important part that every organization must have in facing the era of industry 4.0. This study aims to analyze the mediating impact of organizational learning in strengthening the influence of transformational leadership and job satisfaction on readiness to change. The population and sample of the research are employees of the Department of Transportation and the Department of Communication and Information in the city of Padang, totaling 107 employees. This study uses structural equation model models (SEM) with SmartPLS 3 analysis tools. The results of the study concluded that transformational leadership, job satisfaction, and learning organization have a positive and significant influence on readiness to change. Furthermore, it was also found that transformational leadership and job satisfaction also had a significant effect on learning organizations. The mediating effect in the study found that the learning organization variable was able to provide an additional influence on transformational leadership and job satisfaction in strengthening its influence on readiness to change.
\end{abstract}

Jel Classification:

D23; L20; $M 14$

Keywords: Transformational Leadership, Job Satisfaction, Learning Organization and Readiness to Change 


\section{INTRODUCTION}

The ongoing challenges of the industrial era 4.0 have impacted all lines of work in organizations or companies. Some work that used to be able to be done manually began to be replaced one by one by artificial intelligence on machines designed to help companies or organizations operate. For this reason, organizations must be able to improve the competence and quality of human resources, so they have the readiness to change to provide guarantees and support the sustainability of the organization in the future. The readiness of individuals to change (readiness for change), according to Holt, Armenakis, Feild, and Harris (2007) is a reflection of comprehensive attitudes that are simultaneously influenced by content (what changes), processes (how changes are implemented), context (the environment in which changes occur), and individuals (characteristics of individuals who are asked to change) are involved in a change. In other words readiness to change includes all factors both internal organization (employees, organizational culture and policies or regulations), as well as external factors that must be managed by the organization (market, customers (community), competitors or partners or other parties who helped the operational activities of the organization). This is in line with what was stated by Putra and Fitri (2018), that every business and public sector organization needs individual readiness to change in each of its operations.

As one of the local government work units (SKPD) of the Department of Transportation and the Office of Communication and Information Technology in the city of Padang, is the spearhead in community service in the field of transportation (transportation, traffic) and data or information communication systems that support the implementation of order in traffic on the road, both land, sea and air. So the readiness to change is very much needed in the era of digitalization which demands maximum service to the community by utilizing information system technology advancements. Past experiences faced by these two government institutions, when there was a bureaucratic transformation in 2015, these two services were the Transportation Department combined with the Communication and Information Office (Kominfo) to become one institution. Various obstacles and challenges with different HR competencies have impacted, inequality in terms of employee placement and policies, which one of the two agencies must be able to become one cohesiveness. Although in the utilization of human resources and economic resources that are sometimes not balanced, as in the organizational structure of the Transportation Department there are 4 fields while the Communication and Information Agency is only represented by one field. So that this also indirectly affects the readiness to change as well as the increasingly high potential for cynicism about the changes themselves, (Putra \& Fitri, 2018).

So that since this policy, both institutions can focus back to work in accordance with their Vision and Mission with competence Existing human resources and economic resources. So the readiness to change in restructuring an organization that is in line with internal and external environmental challenges becomes the main priority for both organizations in maximizing their services to the community. In addition, past experience is also a strength for learning for organizations in evaluating and measuring the ability of organizations in readiness to change, (Putra \& Fitri, 2018).

An empirical study of readiness for change conducted by Putra and Fitri (2018), with transformational leadership factors, information sharing, job satisfaction, and cynicism in assessing their influence on readiness for change, found that all three factors were able to contribute in explaining flickering to change. The results of Rafferty, Jimmieson, and Armenakis 
(2013), research, related to readiness to change also concluded that leadership has a good impact on shaping readiness to change in organizations. Another study by Junita and Hermansyur (2014), regarding learning organizations as predictors of organizational change readiness, found that there was a significant effect of learning organizations on organizational change readiness. Based on the problems and research findings above, the researcher makes this research gab in the form of an assessment of the mediating effect of learning organization variables in strengthening the influence of transformational leadership and job satisfaction on readiness to change for employees of the Transportation Office and the Communication and Information Office in Padang.

While Holt, Armenakis and Harris (2009), argue that readiness to change when employees have a comprehensive attitude that describes the content (what changes), the process (how changes are implemented), the context (the environment in which changes occur), and individuals (individual characteristics that are asked to change) in the change. In other words, readiness to change is determined by the support of the attitudes and behavior of each individual in order to help achieve the goals in these changes. This was revealed by Putra and Fitri (2018), employees who have readiness to change have a positive perception that the changes made will be able to provide good progress and growth for the organization in the future.

Leadership is an important part that must exist in an organization. The ability to exist leadership will be able to bring the organization to achieve its vision and mission. Leadership is the art or style of a leader in empowering the full potential of the organization in increasing employee productivity in achieving the goals of the organization. Transformational leadership is leadership that breaks down and opposes the status quo to change for the better,
(Lensufiie, 2010). Job satisfaction can be expressed as a form of pleasure or unpleasant that exists in the employee towards the job and the organization where he works. As expressed by Luthans, Youssef, and Avolio (2015), describing job satisfaction is a positive or negative attitude carried out individually towards their work. In other words, a person with high job satisfaction will position himself to support these changes, such as in terms of having the readiness to change and having an effort to learn about the changes themselves. Armenakis, Harris \& Mossholder, in Holt et al. (2007), in Putra and Fitri (2018), said individuals who have readiness to change are marked by positive attitudes about wanting to engage in change and believe that changes made by organizations will bring progress and development to the organization in the future.

Learning organization or learning organization is one of the important themes in organizational studies when external conditions change. Learning organizations include learning individually, in groups, and organizations by encouraging a continuous process for organizational and individual learning, (Chang \& Lee, 2007). Tjakraatmadja and Lantu (2006), emphasizes that Learning organization is an organization that prioritizes learning. Ideally every worker has a commitment to continue to improve themselves through learning. The hypothesis formulation of this study is to assess the effect of transformational leadership, job satisfaction and learning organization on readiness to change. Furthermore, this study also assessed the effect of transformational leadership and job satisfaction on learning organizations. Furthermore, this study will also assess the effect of the indirect effect of learning organizations on Transportation and Employees of the Office of Communication and Information in the City of Padang. This study aims to analyze the mediating impact of organizational learning in strengthening 
the influence of transformational leadership and job satisfaction on readiness to change.

\section{METHODS}

The population and sample of the study included all employees of the Department of Transportation and the Office of Communication and Information in the City of Padang. The collection technique uses a research questionnaire. The definition and measurement of research variables include variables:

a) Readiness to change is a picture of the attitudes and behavior of employees in an effort to prepare themselves to change the Employees of the Transportation Office and the Communication and Information Office in Padang. The evaluation of this variable refers to the indicators developed by Yousef (2000) which include resourcefulness, optimism, adventurousness, drive, adaptability, confidence, tolerance for Transformational.

b) Transformational leadership is a picture of the ability of leaders who inspire employees in generating work morale, motivation, and commitment to the readiness of individuals to change.

c) Job satisfaction is a feeling of pleasure and unpleasant employees in carrying out their duties and obligations. The assessment of this variable uses a questionnaire with the following indicators: a). The satisfaction of salary/wages, b). Satisfaction with promotions, c). Satisfaction with colleagues, d). Satisfaction with supervision/supervisor and e). Job satisfaction, (Mas'Ud, 2004).

Learning organizations include

learning individually, in groups, and organizations by encouraging a continuous process for organizational and individual learning. Measurement of this variable uses a questionnaire designed based on 5 indicators of the learning organization, (Mukharomah, 2013).

\section{Data Analysis Techniques}

The research data analysis technique uses Partial Least Square (PLS). This method is believed to be superior and powerful, because it does not require as many assumptions as analysis techniques in general, (Ghozali, 2008). Another advantage is that the PLS method does not require multivariate normally distributed data, the data can have a category scale, ordinal, the interval to the ratio and sample size can be relatively low or not necessarily large, (Jogiyanto \& Abdillah, 2009). To test this research model SmartPLS Software 3. The testing process will go through 2 (two) stages:

a) Outer model or measurement model.

The measurement model, in essence, relates to assessing validity and reliability. A validity test is measured using Convergent validity value of 0.5 , (Ghozali, 2008). Reliability tests are measured using Crombach alpha and composite reliability, with a value limit of each of. 0.6 and 0.7 or 0.6 can still be accepted, (Ghozali, 2008).

b) Inner model.

This model is related to the assessment of the research hypothesis, which begins with the evaluation of the model through the value of $\mathrm{R}^{2}$, ( $\mathrm{R}$ Squares). Besides that, the value of $\mathrm{R}^{2}$ serves to measure the contribution of endogenous variables in predicting the value of endogenous variables. The higher $\mathrm{R}^{2}$ value indicates a better prediction model. Assessment accepted or rejected hypothesis, can use the value of the probability value or the value of $\mathrm{T}$ statistics or $\mathrm{T}$ Count. If the significance value is small than 0.05 or the calculated $\mathrm{T}$ value is large from $\mathrm{T}$ Table of 1.96, then the hypothesis can be accepted. But if the significance value is small big than 0.05 or $\mathrm{T}$ Count $<1.96$, the hypothesis is rejected, (Ghozali, 2008).

\section{RESULTS AND DISCUSSION}

The results of data analysis through

SmartPLS 3, for the outer model test 
related to validity and reliability, are

presented in the following table:

Table 1. Outer Model Summary

\begin{tabular}{lccc}
\hline \multicolumn{1}{c}{ Construct } & $\begin{array}{c}\text { Number of } \\
\text { Statement Items }\end{array}$ & $\begin{array}{c}\text { Number of } \\
\text { Invalid Statement } \\
\text { Items }\end{array}$ & $\begin{array}{c}\text { Number of } \\
\text { Final Items }\end{array}$ \\
\hline Readiness to change & 18 & 3 & 15 \\
Transformational leadership & 18 & 2 & 16 \\
Job satisfaction & 19 & 4 & 15 \\
Learning organization & 14 & 2 & 12 \\
\hline Source: Processed from
\end{tabular}

Source: Processed from Primary Data

From the table above, we can see the number of valid statement items for each research variable from the outer model test results. With the final number of items from each research variable being used for further testing, invalid items must be excluded from the model and not included in further testing. Furthermore, data testing will continue for inner model testing, this test relates to testing the research

hypothesis. This test is directly related to testing the direct effect (direct effect) and those related to the indirect effect (indirect effect). The results of data analysis on the inner model are presented in 2 parts, first in the form of path analysis and Result for inner weights that describe the relationship or influence of each research variable. Following is a summary of the inner model test results in the table below:

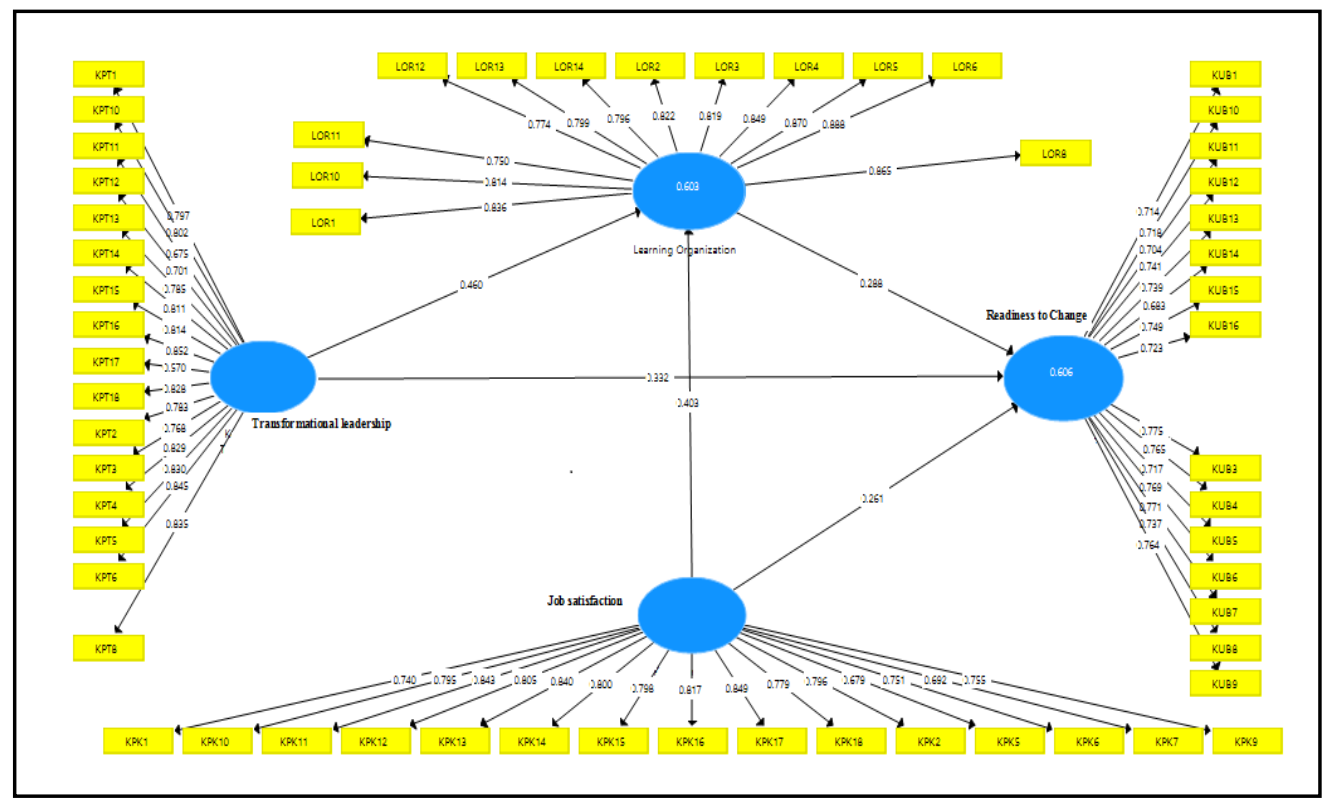

Figure 2

Path Analysis

From the path analysis, it can be seen the relationship of each exogenous variable (transformational leadership, job satisfaction, and learning organization) with endogenous variables, namely readiness to change. Indirectly, path analysis also illustrates the research hypothesis, both related to direct and indirect effects through intervening variables. This assessment can be done by 
paying attention to the direction of the arrow and the coefficient value of certain exogenous variables to certain endogenous variables. Furthermore, the output result or inner weigh is useful in the assessment of research hypotheses. Here is the result of inner weigh table:

Table 2. Result For Inner Weights

\begin{tabular}{|c|c|c|c|c|}
\hline Hypothesis & $\begin{array}{l}\text { Original } \\
\text { Sample }(O)\end{array}$ & T Statistics) & $\begin{array}{l}\text { Probability } \\
\quad \text { (Sig) }\end{array}$ & Conclusion \\
\hline $\begin{array}{l}\text { Transformational Leadership -> } \\
\text { Readiness to Change }\end{array}$ & 0,332 & 2,503 & 0,013 & $\begin{array}{l}\text { Hypothesis } \\
\text { accepted }\end{array}$ \\
\hline Job Satisfaction -> Readiness to Change & 0,261 & 2,801 & 0,005 & $\begin{array}{l}\text { Hypothesis } \\
\text { accepted }\end{array}$ \\
\hline $\begin{array}{l}\text { Transformational Leadership -> Learning } \\
\text { Organization }\end{array}$ & 0,460 & 3,561 & 0,000 & $\begin{array}{l}\text { Hypothesis } \\
\text { accepted }\end{array}$ \\
\hline Job Satisfaction -> Learning Organization & 0,403 & 4,362 & 0,000 & $\begin{array}{l}\text { Hypothesis } \\
\text { accepted }\end{array}$ \\
\hline $\begin{array}{l}\text { Learning Organization -> Readiness to } \\
\text { Change }\end{array}$ & 0,288 & 2,101 & 0,036 & $\begin{array}{l}\text { Hypothesis } \\
\text { accepted }\end{array}$ \\
\hline $\begin{array}{l}\text { Transformational Leadership }->\text { Learning } \\
\text { Organization }->\text { Readiness to Change }\end{array}$ & 0,132 & 1,368 & 0,172 & $\begin{array}{l}\text { Hypothesis } \\
\text { rejected }\end{array}$ \\
\hline $\begin{array}{l}\text { Job Satisfaction } \rightarrow \text { Learning Organization } \\
->\text { Readiness to Change }\end{array}$ & 0,116 & 2,449 & 0,015 & $\begin{array}{l}\text { Hypothesis } \\
\text { accepted }\end{array}$ \\
\hline
\end{tabular}

Source: Processed from Primary Data

\section{Transformational leadership influences readiness to change}

Based on the results of the inner model test on the result of inner weigh, found that transformational leadership has a positive and significant effect on readiness to change in Transportation and Employees in the Office of Communication and Information Technology in Padang. With a regression coefficient of 0.332 with a t-statistic or t-count of 2.503 with a significant value of 0.013 , where the significant value produced is smaller than the error rejecting the data of 0.05 or 0.013 $<0.05$, thus the hypothesis can be accepted. From this finding it can be interpreted that transformational leadership is an important factor that determines readiness to change according to its nature of leadership which provides changes to organizational attitudes and behavior and seeks to provide reinforcement to all individuals who are in it in the form of readiness to change. This finding is also in line with the theoretical foundation which says that good leadership will have many positive impacts on organizational life, (Hasibuan, 2010). The results of the hypothesis can strengthen the research results of Putra and Fitri (2018), Lyons, Swindler, and Offner (2009), that transformational leadership can influence an individual's readiness to change. Research findings (Glew, 2009), also show that an individual's readiness to change is determined one of them by transformational leadership.

\section{Job satisfaction affects the readiness to change}

The results of the inner model test on the result of inner weigh, also showed that the factor of job satisfaction proved to be able to have a positive and significant effect on readiness to change in the Transportation Department and Communication and Information Technology Employees in the City of Padang. Where the regression coefficient value of 0.261 with a t-statistic or t-count of 2.801 with a significant value of 0.005 , where the significant value generated is smaller than the error rejecting the data of 0.05 or $0.005<0.05$ so this hypothesis can also be proven or accepted. The results of this study can be interpreted, that the readiness to change is also determined by the extent to which the organization can 
meet the level of satisfaction given to its employees in order to motivate employees to support a change in the organization. This fulfillment can be in the form of increased compensation, ease of work and other support both from leadership or other factors in the form of an increasingly better organizational environment.

The results of this hypothesis can also strengthen research conducted by Putra and Fitri (2018), Sijabat (2011) who found that there was a significant effect of job satisfaction on the desire to change. While research (Lipińska-Grobelny \& Papieska, 2012), also concluded that the readiness to change in an organization is determined by the level of job satisfaction of individuals within the organization.

\section{Transformational influences the learning organization}

Based on a summary of the results or inner weigh, it can be seen that transformational leadership is also a factor affecting learning organizations in Transportation and Information and Communication Department Employees in Padang City. Where the regression coefficient value of 0.460 with a t-statistic or t-value of 3,561 with a significant value of 0,000 . If compared significant value with alpha value or error rejecting data of 0.05 , then the resulting significant value is smaller than 0.05 or $0.000<0.05$, so this hypothesis can also be proven or accepted. The results of this hypothesis also reveal that transformational leadership is also able to be a determinant or driving force in organizations in learning organizations. Where transformational leadership has an important role to be able to make every individual that exists as an agent in change and try to encourage each individual that is able to make the moment of bureaucratic transformation become part of learning in the organization so that the organization has good sustainability in the future.

This finding is also reinforced by the theoretical foundation of Hasibuan (2010), stating the application of strong leadership can have a positive impact on organizational life. This can also mean that leadership must be able to direct all individuals in the organization to learn about the changes that occur in the organization. The findings of this hypothesis are in accordance with the results of research conducted by Khodaparast Sereshkeh and Amirnejad (2013) which found a significant relationship between leadership and learning organization. Furthermore, Asmony and Husnan (2017) found that there was a significant influence of transformational leadership on readiness to change. Furthermore, Nordin (2012) research (2012) states that leadership behavior and organizational commitment on organizational readiness for change is a type of transformational leadership that also has a role in organizational success in readiness to change through organizational learning.

\section{Job satisfaction affects the Learning organization}

The inner model test results on the result or inner weigh, show that job satisfaction can significantly affect learning organizations in Transportation and Information and Communication Department Employees in Padang City. Where the regression coefficient is 0.403 with a t-statistic or t-count of 4.362 with a significant value of 0.000 . If compared significant value with alpha value or error rejecting data of 0.05 , then the resulting significant value is smaller than 0.05 or $0.000<0.05$, therefore the hypothesis can be accepted. This finding also indicates that the level of job satisfaction also encourages individuals in the organization to have the behavior and desire to learn to have the ability and knowledge to support their work. The theoretical study of learning organizations explained by Watkins and Marsick (2003) that a systematic approach to learning in organizations is related to the performance and survival of a company or organization in determining the value of the future. Egan, Yang, and Bartlett (2004) state that there is a close relationship 
between learning culture in organizations with satisfaction at work. While the research of Rose, Kumar, and Pak (2009) also found a significant relationship and influence between job satisfaction and learning culture, also found a significant relationship between the two variables.

\section{Learning organization influences readiness to change}

The results of SmartPLS 3 testing on the result or inner weigh, indicate that the learning organization is able to explain the readiness to change for the Transportation and Employees of the Communication and Information Technology Office in Padang. Where the regression coefficient value of 0.288 with a t-statistic or t-count of 2.101 with a significant value of 0.036 . Where the resulting significance is less than 0.05 or $0.036<0.05$, thus the hypothesis of this study can also be proven or accepted. These findings also explain that learning in organizations (learning organizations) become an important part and determine the readiness of individuals to change. Through this learning individuals within the organization will gain strength and knowledge of why organizations need changes in their activities. This finding is also in line with the opinion of Peach, Jimmieson, and White (2005), defining preparation for change is the positive attitude of staff or the need to change and also their belief that change can be a positive implication for them and the organization. He further said Preparation and attitude (learning organization) for change among members of an organization are known as key success factors for change efforts.

The findings of this hypothesis are relevant to research conducted by Khodaparast Sereshkeh and Amirnejad (2013), his findings conclude there is a direct relationship between learning organizations and readiness to change. Furthermore, Sudharatna and Li (2004) research also confirms that employee characteristics in learning correlate with organizational readiness-for-change and it is very important for organizations to develop into survival and/or prosper in competition and changes in the business environment.

\section{Transformational leadership influences readiness to change through learning organizations}

The result of inner weigh, states that the learning organization is not able to mediate the influence of transformational leadership in determining readiness to change for Transportation and Employees in the Office of Communication and Information Technology in Padang. Where the regression coefficient value of 0.132 with a t-statistic or t-value of 1.368 with a significant value of 0.172 . Where the resulting significance is greater than 0.05 or $0.172>0.05$, thus this hypothesis is declared rejected or unproven. This finding can be interpreted that the existing leadership has not been able to optimally provide maximum motivation in implementing learning organizations in shaping readiness to change in the face of organizational transformation that occurs.

Research related to the role of learning organization variables in strengthening the effect of transformational leadership on readiness to change, until this study was conducted researchers have not found it. However, research conducted by Nordin (2012) is slightly different, which assesses the effect of leadership behavior on readiness to change that makes the organizational commitment a mediating variable. His findings found that organizational commitment has a good role in strengthening the influence of leadership behavior on readiness to change. Further research by Aarons, Ehrhart, Farahnak, and Hurlburt (2015).

\section{Job satisfaction influences readiness to change through the Learning organization}

The results of the result or inner weigh, found a significant effect of job satisfaction on readiness to change through the variable learning organization of the Transportation and Employees of the 
Office of Communication and Information Technology in the city of Padang. Where the regression coefficient is 0.116 with a $\mathrm{t}-$ statistic or t-count of 2.449 with a significant value of 0.015 . Where the resulting significant value is smaller than 0.05 or $0.013<0.05$, thus this hypothesis can be accepted. These results indicate that learning organizations can mediate in strengthening the effect of job satisfaction on readiness to change. In other words, the increase in job satisfaction received by employees has an impact on improving employee attitudes and behavior for learning related to knowledge, abilities and shared work experience that can ultimately strengthen the individual's readiness to change.

Research findings related to this hypothesis are relatively undiscovered, but if seen from the three direct influences that form this hypothesis, there is a significant influence between job satisfaction on readiness to change and on learning organizations. While also found a significant effect of learning organizations on readiness to change. As research Putra (2016), it can be interpreted that the existing leadership has not been able to optimally provide maximum motivation in implementing learning organizations in shaping readiness to change in the face of organizational transformation that occurs.

\section{CONCLUSIONS}

Finally, this study concludes, that the factors of transformational leadership, job satisfaction, and learning organization are the factors needed to shape the readiness of individuals to change. Furthermore, this study also found that learning organizations within employees are determined by the strong transformational leadership role and job satisfaction possessed by employees at work. Furthermore, the effect of mediation or intervening of the learning organization variable in this study is only able to mediate the effect of job satisfaction on readiness to change in individuals. While transformational leadership is not proven to be significantly mediated by learning organizations in strengthening individuals' readiness to change.

\section{REFERENCE}

Aarons, G. A., Ehrhart, M. G., Farahnak, L. R., \& Hurlburt, M. S. (2015). Leadership And Organizational Change For Implementation (LOCI): A Randomized Mixed Method Pilot Study Of A Leadership And Organization Development Intervention For Evidence-Based Practice Implementation. Implementation science, 10(1), 11.

Armenakis, A. A., \& Harris, S. G. (2009). Reflections: Our Journey In Organizational Change Research And Practice. Journal of change management, 9(2), 127-142.

Asmony, T., \& Husnan, H. (2017). Pengaruh Kepemimpinan Transformasional Dan Iklim Psikologis Terhadap Kesiapan Untuk Berubah Karyawan Puskesmas Kabupaten Lombok Barat Dalam Rangka Akreditasi Dan Komitmen Afektif Sebagai Variabel Intervening.

Chang, S.-C., \& Lee, M.-S. (2007). A Study On Relationship Among Leadership, Organizational Culture, The Operation Of Learning Organization And Employees' Job Satisfaction. The Learning Organization, 14(2), 155-185.

Egan, T. M., Yang, B., \& Bartlett, K. R. (2004). The Effects Of Organizational Learning Culture And Job Satisfaction On Motivation To Transfer Learning And Turnover Intention. Human Resource Development Quarterly, 15(3), 279301.

Ghozali, I. (2008). Fuad. Structural Equation Modeling: Teori, Konsep, dan Aplikasi.

Glew, D. J. (2009). Personal Values And Performance In Teams: An 
Individual And Team-Level Analysis. Small Group Research, 40(6), 670-693.

Hasibuan, M. S. (2010). Manajemen Sumber Daya Manusia: Bumi Aksara.

Holt, D. T., Armenakis, A. A., Feild, H. S., \& Harris, S. G. (2007). Readiness For Organizational Change: The Systematic Development Of A Scale. The Journal of applied behavioral science, 43(2), 232-255.

Jogiyanto, H., \& Abdillah, W. (2009).

Konsep Dan Aplikasi PLS (Partial Least Square) Untuk Penelitian Empiris. BPFE Fakultas Ekonomika dan Bisnis UGM. Yogyakarta.

Junita, A., \& Hermansyur, M. (2014). Learning Organization Sebagai Prediktor Kesiapan Berubah Organisasi. Jurnal Dinamika Akuntansi dan Bisnis, 1(2), 107118.

Khodaparast Sereshkeh, S., \& Amirnejad, S. (2013). The Relationship Between Organizational Learning and Readiness for Change in the Staff of Physical Education Offices. Annals of Applied Sport Science, 1(1), 19-22.

Lensufiie, T. (2010). Leadership Untuk Profesional Dan Mahasiswa. Jakarta: Erlangga.

Lipińska-Grobelny, A., \& Papieska, E. (2012). Readiness For Change And Job Satisfaction In A Case Of Lean Management Application-A Comparative Study. International Journal Of Occupational Medicine And Environmental Health, 25(4), 418-425.

Luthans, F., Youssef, C. M., \& Avolio, B. J. (2015). Psychological Capital And Beyond: Oxford University Press, USA.

Lyons, J. B., Swindler, S. D., \& Offner, A. (2009). The Impact Of Leadership On Change Readiness In The US
Military. Journal of Change Management, 9(4), 459-475.

Mas'Ud, F. (2004). Survai Diagnosis Organisasional Konsep dan Aplikasi. Badan Penerbit Universitas Diponegoro.

Mukharomah, W. (2013). Strategi Mengelola Perubahan Melalui Learning Organisation Industri Kecil dan Menengah pada Industri Batik di Kota Surakarta.

Nordin, N. (2012). The Influence Of Leadership Behavior And Organizational Commitment On Organizational Readiness For Change In A Higher Learning Institution. Asia Pacific Education Review, 13(2), 239-249.

Peach, M., Jimmieson, N. L., \& White, K. M. (2005). Beliefs Underlying Employee Readiness To Support A Building Relocation: A Theory Of Planned Behavior Perspective. Organization Development Journal, 23, 9-22.

Putra, R. B. (2016). Efek Mediasi Kepuasan Kerja terhadap Kinerja dengan Komitmen Organisasi, Komunikasi Interpersonal dan Organizational Citizenship Behaviors sebagai Variabel Anteseden. Jurnal Praktik Bisnis, 5(1), 95-110.

Putra, R. B., \& Fitri, H. (2018). Efek Mediasi Sinisme Terhadap Kesiapan Untuk Berubah Dengan Kepemimpinan Transformasional, Information Sharing Dan Kepuasan Kerja Sebagai Variabel Antenseden.

Rafferty, A. E., Jimmieson, N. L., \& Armenakis, A. A. (2013). Change readiness: A multilevel review. Journal of management, 39(1), 110135.

Rose, R. C., Kumar, N., \& Pak, O. G. (2009). The Effect Of Organizational Learning On Organizational Commitment, Job Satisfaction And Work 
Performance. Journal of Applied Business Research (JABR), 25(6).

Sijabat, J. (2011). Pengaruh Kepuasan Kerja Terhadap Komitmen Organisasi Dan Keinginan Untuk Pindah. Jurnal Visi, 19(3), 592-608. Sudharatna, Y., \& Li, L. (2004). Learning Organization Characteristics Contributed To Its Readiness-ToChange: A Study of The Thai Mobile Phone Service Industry. Managing Global Transitions, 2(2), 163.

Tjakraatmadja, J. H., \& Lantu, D. C. (2006). Knowledge Management In The Context Of Learning Organizations. School of Business and Management (SBM) Bandung Institute of Technology, Bandung. Watkins, K. E., \& Marsick, V. J. (2003). Making Learning Count! Diagnosing The Learning Culture In Organizations. Advances In Developing Human Resources, 5(2), 132-151.

Yousef, D. A. (2000). Organizational Commitment: A Mediator Of The Relationships Of Leadership Behavior With Job Satisfaction And Performance In A Non-Western Country. Journal Of Managerial Psychology, 15(1), 6-24. 